\title{
NEW DATA CONCERNING THE FRESHWATER MOLLUSCS FROM THE ROMANIAN SECTOR OF TIMIŞ RIVER (BANAT, ROMANIA)
}

\author{
Ioan SÎRBU * and Monica SÎRBU **
}

\begin{abstract}
* "Lucian Blaga" University of Sibiu, Faculty of Sciences, Department of Environmental Sciences and Physics, 5-7 Raţiu St., RO-550012 Sibiu, Romania, meosirbu@yahoo.com

** "Andrei Şaguna" Pedagogical National College, 2 Aleea Turnu Roşu St., RO - 550361 Sibiu, Romania, monisirbu70@yahoo.com
\end{abstract}

DOI: 10.2478/trser-2013-0035

KEYWORDS: chorology, bioindication, human impact, community, invasive species.

\begin{abstract}
In the Romanian sector of the Timiş River, 31 species of freshwater molluscs have been found up to the present. Among them are 17 gastropod and 14 bivalve species (including all seven species of Unionidae that live in Romania, these found in the lower sector of the river - something that is extremely rare in our waters). The present synthesis used the results of a screening type field investigation carried out in 2011, as well as all the available data from the literature and our previous studies. All these data prove the ongoing degradation of the river's ecological state and its sheltered communities. This paper presents the annotated systematic and chorological checklist of the mollusc species from this area, some of its ecological characteristics and the main environmental issues related to human impact. Changes in species distribution and the structure of communities as an answer to increased human pressure during the last decades are also thus demonstrated. New data about some alien invasive species are given, including the first encounter with Corbicula fluminea, a species formerly known only in Romanian inland waters from the Danube, in the Timiş River lower sector.

RÉSUMÉ: Nouvelles données sur les mollusques d'au douce du secteur roumain de la rivière Timiş (Banat, Roumanie).

Dans le secteur roumain de la rivière Timiş, 31 espèces de mollusques d'eau douce ont été trouvées jusqu'à présent. Parmi celles-ci se trouvent 17 espèces de gastéropodes et 14 espèces de bivalves ( $\mathrm{y}$ compris les sept espèces d'unionidae roumaines se trouvant dans le secteur inférieur de la rivière - ce qui est extrêmement rare dans nos eaux). Dans la présente synthèse, les résultats d'une campagne de terrain faite en 2011, les résultats de nos études antérieures et toutes les données disponibles dans la littérature ont été utilisés. Toutes ces données confirment la dégradation continue de l'état écologique de la rivière ainsi que de ses communautés. Cet article présente la liste systématique et chorologique des espèces de mollusques de cette zone, certaines de leurs caractéristiques écologiques et les principaux problèmes environnementaux liés à l'impact des activités humaines. Les changements de la distribution des espèces et de la structure des communautés, comme une réponse à l'augmentation de la pression humaine au cours des dernières décennies, sont également indiqués dans cette synthèse. De nouvelles données sur certaines espèces exotiques invasives sont présentées, y compris le premier relevé de Corbicula fluminea dans le secteur inférieur de la rivière Timiş, une espèce autrefois connus dans les eaux intérieures roumaines du Danube.
\end{abstract}


REZUMAT: Noi date cu privire la moluştele dulcicole din sectorul românesc al râului Timiş (Banat, România).

În sectorul râului Timiş din Banat, România, au fost identificate până în prezent 31 de specii de moluşte dulcicole, dintre care 17 specii de gastropode şi 14 de bivalve (inclusiv toate cele şapte specii de Unionidae care trăiesc în România au fost identificate în sectorul inferior al râului, fapt care se constată extrem de rar în apele noastre). În sinteza de faţă sunt utilizate toate datele originale şi bibliografice, la care se adaugă rezultatele unei campanii de cercetare desfăşurate în 2011, toate acestea demonstrând continua degradare a stării ecologice a râului şi a comunităţilor adăpostite de acesta. Lucrarea de faţă prezintă o listă actualizată sistematică şi corologică a speciilor, unele observaţii cu privire la ecologia lor, precum şi principalele probleme legate de impactul antropic în aria de referinţă. Modificări spaţiale şi temporale ale distribuţiei speciilor şi ale structurii comunităţilor, ca răspuns la presiunile antropogene, sunt de asemenea prezentate. Noi date privind unele specii alohtone invazive sunt prezentate, inclusiv prima semnalare a speciei Corbicula fluminea în sectorul inferior al Timişului, cunoscută anterior în România numai din apele Dunării.

\section{INTRODUCTION}

The Banat is the southwestern province of Romania, bordered by the Mureș River in the North, the Danube in the South and the Southern Carpathian mountains in the East. The Timiş River drains a significant part of its central and northern area. It is the largest interior river from Banat, originating from Semenic Mountains, with a length of $339.7 \mathrm{~km}(241.2 \mathrm{~km}$ on Romanian territory) and a surface of the hydrographic basin of $13.085 \mathrm{~km}^{2}$. It passes outside the Romanian border at Grăniceri locality, which is the last sampling station concerning the present paper. The remaining $100 \mathrm{~km}$ are on Serbian territory and at the level of the Pančevo locality it flows into the Danube. Some scattered material and information regarding the freshwater Mollusca from Banat date back to the XIXth Century. Most naturalists studied terrestrial molluscs, especially from mountain areas, the aquatic species being only seldom quoted. The few mentions usually give no exact toponyms. However, some data are available from the collections of Bielz, Kimakowicz, Licherdopol, Grossu, and others. These collections are preserved mainly in the Museum of Natural History in Sibiu and the "Grigore Antipa" National Museum of Natural History in Bucharest. Some published historical data are available from Bielz (1867), Kimakowicz (1883-1884), and Clessin (1887). In the XXth Century, the faunistical data become more numerous. Most papers from the middle part of the century, concerning also the freshwater Mollusca, belong to Grossu and were synthesized in his tomes concerning the bivalves $(1962)$ and the gastropods $(1986,1987)$ from Romania. Beginning with 1998 the authors of the present paper organized several sampling trips in the Romanian Banat, inclusively the Timiş River, which was researched three times along its entire Romanian course, from the source area down to the point it passes outside the border. Some published papers, with references to this subject and area, dealt with the distribution of the Pisidium species in Banat (Sîrbu, 2002; Sîrbu and Benedek, 2004), data regarding the diversity of the freshwater species from Banat (Bănărescu and Sîrbu, 2002), the Mollusca fauna from Timiş River (Sîrbu, 2004), data regarding the distribution and ecology of several groups from the regional molluscs' fauna (Sîrbu et al., 2006; Sîrbu et al., 2010; Sîrbu, 2011). The freshwater molluscs from this river are better known compared to those from most of the Romanian running waters. However, during the screening type field survey, carried out by the authors in 2011, some new and remarkable features of mollusc communities have been discovered. Among them, the propagation of a new invasive species, changes in the longitudinal species distribution and in communities structure, in the presence and magnitude 
of the human impact. Thus, based on new evidence, the authors highlight the changes that occurred in the ecological state of the river and its freshwater molluses during the last decade. The field survey from August 2011 was done in the frame of a study concerning the quality of the Timiş River, from the springs down to the border with Serbia, as a part of a RomanianSerbian partnership program.

\section{STUDY AREA AND METHODS}

The annotated checklist of freshwater molluscs from the Timiş River (Romanian territory) is based on all available references and collections, as well as on the authors' research accomplished since 1998. The new data are coming from a field survey, carried on in August 2011. The sampling sites were selected according to geomorphologic and hydrologic features, but also to the presence of human impact sources. The molluscs were sampled by hand, by sieves or dredges. The naiads (Unionidae bivalves) were random sampled, studied, measured, weighted and released in their natural habitat. Experimental and sampling designs were adapted adequately to the local features of each station.

The sampling stations from 2011 are localized, codified and characterized according to table 1 (the GPS coordinates are given in terms of degrees and decimal minutes).

Table 1: Sampling stations along the Timiş River, during August 2011 field survey.

\begin{tabular}{|c|c|c|}
\hline Code & GPS coordinates & Sampling station's toponime and features \\
\hline S1 & $\begin{array}{l}45^{0} 11.994^{\prime} \mathrm{N} / 22^{0} 08.408^{\prime} \mathrm{E} \\
\text { Elevation }=862 \mathrm{~m}\end{array}$ & $\begin{array}{l}\text { Timiş riverbed (Semenic Valley), as well as ponds } \\
\text { and brooks in the flood area. }\end{array}$ \\
\hline S2 & $\begin{array}{l}45^{0} 13.139^{\prime} \mathrm{N} / 22^{0} 06.204^{\prime} \mathrm{E} \\
\text { Elevation }=850 \mathrm{~m}\end{array}$ & $\begin{array}{l}\text { Grădişte brook tributary of the Trei Ape Lake, } \\
\text { between the villages of Gărâna and Brebu Nou, as } \\
\text { well as brooklets and helokrenik springs. }\end{array}$ \\
\hline S3 & $\begin{array}{l}45^{0} 13.679^{\prime} \mathrm{N} / 22^{0} 08.904^{\prime} \mathrm{E} \\
\text { Elevation }=847 \mathrm{~m}\end{array}$ & $\begin{array}{l}\text { Brook tributary of the Trei Ape Lake, } 100 \mathrm{~m} \text { upstream } \\
\text { its flow, at the level of Brebu Nou Village. }\end{array}$ \\
\hline S4 & $\begin{array}{l}45^{0} 12.648^{\prime} \mathrm{N} / 22^{0} 08.879^{\prime} \mathrm{E} \\
\text { Elevation }=847 \mathrm{~m}\end{array}$ & $\begin{array}{l}\text { Brooklets and springs near the banks of the Trei Ape } \\
\text { Lake. }\end{array}$ \\
\hline S5 & $\begin{array}{c}\text { Transect between: } \\
45^{0} 13.137^{\prime} \mathrm{N} / 22^{0} 07.688^{\prime} \mathrm{E} \\
\text { and } 45^{\circ} 12.914^{\prime} \mathrm{N} / 22^{0} 08.693^{\prime} \mathrm{E} \\
\text { Elevation }=847 \mathrm{~m}\end{array}$ & $\begin{array}{l}\text { The Trei Ape Lake (artificially built dam-lake; } \\
\text { transect done by boat and dredging) }\end{array}$ \\
\hline S6 & $\begin{array}{l}45^{0} 12.823^{\prime} \mathrm{N} / 22^{0} 09.204^{\prime} \mathrm{E} \\
\text { Elevation }=819 \mathrm{~m}\end{array}$ & Timiş River, downstream the Trei Ape Lake \\
\hline S7 & $\begin{array}{l}45^{0} 09.595^{\prime} \mathrm{N} / 22^{0} 16.528^{\prime} \mathrm{E} \\
\text { Elevation }=436 \mathrm{~m}\end{array}$ & $\begin{array}{l}\text { Timiş River, upstream the Teregova locality, close to } \\
\text { the exit from the mountains narrows, upstream its } \\
\text { entrance in the Timiş-Cerna corridor. }\end{array}$ \\
\hline S8 & $\begin{array}{l}45^{0} 13.101^{\prime} \mathrm{N} / 22^{0} 18.277^{\prime} \mathrm{E} \\
\text { Elevation }=333 \mathrm{~m}\end{array}$ & $\begin{array}{l}\text { Timiş River in the Timiş-Cerna corridor, close to the } \\
\text { Piatra Scrisă Monastery. }\end{array}$ \\
\hline S9 & $\begin{array}{l}45^{0} 22.494^{\prime} \mathrm{N} / 22^{0} 13.580^{\prime} \mathrm{E} \\
\text { Elevation }=234 \mathrm{~m}\end{array}$ & $\begin{array}{l}\text { Timiş River, upstream the town of Caransebeş, at } \\
\text { Buchini Village. }\end{array}$ \\
\hline $\mathrm{S} 10$ & $\begin{array}{l}45^{0} 29.129^{\prime} \mathrm{N} / 22^{0} 11.070^{\prime} \mathrm{E} \\
\text { Elevation }=177 \mathrm{~m}\end{array}$ & Timiş River $9 \mathrm{~km}$ downstream the town of Caransebeş \\
\hline S11 & $\begin{array}{c}45^{0} 40.239^{\prime} \mathrm{N} / 21^{0} 58.064^{\prime} \mathrm{E} \\
\text { Elevation }=128 \mathrm{~m}\end{array}$ & Timiş River at Lugojel Village \\
\hline S12 & $\begin{array}{l}45^{0} 44.290^{\prime} \mathrm{N} / 21^{0} 51.263^{\prime} \mathrm{E} \\
\text { Elevation }=117 \mathrm{~m}\end{array}$ & $\begin{array}{l}\text { Entrance in the Timiş-Bega channel, about } 300-400 \\
\mathrm{~m} \text { along the banks, downstream the dam, at Coşteiu.. }\end{array}$ \\
\hline
\end{tabular}


Table 1 (continuing): Sampling stations along the Timiş River, during August 2011 field survey.

\begin{tabular}{|c|c|c|}
\hline Code & GPS coordinates & Sampling station's toponime and features \\
\hline $\mathrm{S} 13$ & $\begin{array}{l}45^{0} 44.290^{\prime} \mathrm{N} / 21^{0} 51.263^{\prime} \mathrm{E} \\
\text { Elevation }=117 \mathrm{~m}\end{array}$ & $\begin{array}{l}\text { Timiş riverbed, downstream the dam at Coşteiu } \\
\text { locality. }\end{array}$ \\
\hline S14 & $\begin{array}{l}45^{0} 43.682^{\prime} \mathrm{N} / 21^{0} 31.678^{\prime} \mathrm{E} \\
\text { Elevation }=99 \mathrm{~m}\end{array}$ & $\begin{array}{l}500 \mathrm{~m} \text { sector of the Timiş River, centered in the } \\
\text { specified coordinates, at the bridge between } \\
\text { Topolovățu Mare and Hitiaș localities. }\end{array}$ \\
\hline S15 & $\begin{array}{l}45^{0} 42.702^{\prime} \mathrm{N} / 21^{0} 24.555^{\prime} \mathrm{E} \\
\text { Elevation }=91 \mathrm{~m}\end{array}$ & $\begin{array}{l}\text { Timis River at the bridge towards Albina Village; } \\
\text { about } 500 \mathrm{~m} \text { researched sector of the riverbed. }\end{array}$ \\
\hline S16 & $\begin{array}{l}45^{0} 38.661^{\prime} \mathrm{N} / 21^{0} 11.035^{\prime} \mathrm{E} \\
\text { Elevation }=88 \mathrm{~m}\end{array}$ & Timiş River at Şag, upstream the dam. \\
\hline S17 & $\begin{array}{c}45^{0} 29.508^{\prime} \mathrm{N} / 21^{0} 00.995^{\prime} \mathrm{E} \\
\text { Elevation }=76 \mathrm{~m}\end{array}$ & Timiş River at Rudna Village \\
\hline S18 & $\begin{array}{c}45^{0} 26.843^{\prime} \mathrm{N} / 20^{0} 53.289^{\prime} \mathrm{E} \\
\text { Elevation }=73 \mathrm{~m}\end{array}$ & $\begin{array}{l}\text { Timiş River at the bridge from Grănceri Village, } \\
\text { upstream the border with Serbia. }\end{array}$ \\
\hline
\end{tabular}

The systematics is given according to Glöer (2002), Glöer and Meier-Brook (2003), than to Fauna Europaea v. 2.6.2, namely the lists compiled by Bank (v. 2.4, updated on 27 January, 2011) for gastropods, and by Araujo (v. 2.0, updated on 10 December 2009) for bivalves, as well as Welter-Schultes (2012). The aim of both the field investigations carried out in 2011 and this paper is to trace the recent changes in environmental quality and human pressure, by using the freshwater molluscs as bioindicators of the river's ecological state

The annotated checklist of freshwater molluscs from the Timiş River (Romanian sector) is given below. Only the new data (i.e. from the investigation carried out in 2011) are explicitly detailed, the former information from references have already been gathered and published in the synthesis of Sîrbu et al. (2010). Thus, only the related sources of older data are given. If only the paper published by Sirbu et al. (2010) is quoted, this mean that the species was found during the field investigations carried out between 1998 and 2002, and more information is available in that synthesis only (available on www.travaux.ro).

The annotated checklist of the freshwater molluscs' species found in the Timiş River

Classis Gastropoda Cuvier, 1795

Ordo Architaenioglossa Haller, 1890

Familia Viviparidae J. E. Gray, 1847 (1883)

1. Viviparus acerosus (Bourguignat, 1862)

References: Sîrbu et al. (2010).

Ordo Neotaenioglossa Haller, 1892

Familia Hydrobiidae Troschel, 1857

2. Lithoglyphus naticoides (Pfeiffer, 1828)

References: Bănărescu leg. (in the years of 1980), Sirrbu et al. (2010).

New data (leg. Sîrbu I. and Sîrbu M., 2011): in the Timiş riverbed at Hitiaş (S14), downstream of Albina (S15), Şag (S16), Rudna (S17) downstream to Grădinari (S18).

3. Bythinella dacica Grossu, 1946

References: Grossu (1946, 1986).

New data (leg. Sîrbu I. and Sîrbu M., 2011): brooks in the Semenic Valley (S1), springs and brooks close to the Trei Ape (S4), and springs near the riverbed, in the valley, upstream Teregova (S7). 
Ordo Ectobranchia P. Fischer, 1884

Familia Valvatidae J. E. Gray, 1840

4. Valvata piscinalis (Müller, 1774)

References: Sîrbu et al. (2010).

Ordo Pulmonata Cuvier in Blainville, 1814

Familia Lymnaeidae Lamarck, 1812

5. Galba truncatula (Müller, 1774)

References: Sîrbu et al. (2010).

New data (leg. Sîrbu I. and Sîrbu M., 2011): along the Timiş riverbanks at Grăniceri (S18).

6. Radix auricularia (Linnaeus, 1758)

New data (leg. Sîrbu I. and Sîrbu M., 2011): Timiş River at Hitiaş (S14) and Rudna (S17).

7. Radix labiata (Rossmässler, 1835)

References: Sîrbu et al. (2010).

New data (leg. Sîrbu I. and Sîrbu M., 2011): brook at Brebu Nou (S3), brooks and puddles near the Trei Ape Lake (S4), Timiş River downstream Trei Ape Lake (S6); brooks and springs upstream Teregova (S7);

8. Radix balthica (Linnaeus, 1758)

New data (leg. Sîrbu I. and Sîrbu M., 2011): Trei Ape Lake (S5).

9. Lymnaea stagnalis (Linnaeus, 1758)

References: Sîrbu et al. (2010).

\section{Familia Physidae Fitzinger, 1833}

10. Physella acuta (Draparnaud, 1805)

References: Sîrbu et al. (2010).

New data (leg. Sîrbu I. and Sîrbu M., 2011): Timiş River at Piatra Scrisă Monastery (S8)

\section{Familia Planorbidae Rafinesque, 1815}

11. Planorbarius corneus (Linnaeus, 1758)

References: Clessin (1887), Sîrbu et al. (2010).

12. Planorbis planorbis (Linnaeus, 1758)

References: Sîrbu et al. (2010).

13. Anisus spirorbis (Linnaeus, 1758)

References: Bielz (1867).

14. Anisus vortex (Linnaeus, 1758)

References: Sîrbu et al. (2010).

15. Gyraulus albus (Müller, 1774)

References: Sîrbu et al. (2010).

New data (lag. Sîrbu I. and Sîrbu M., 2011): Trei Ape Lake (S5).

16. Ferrissia wautieri (Mirolli, 1960)

New data (Sîrbu I. and Sîrbu M., 2011): Trei Ape Lake (S5).

17. Ancylus fluviatilis Müller, 1774

References: Sîrbu et al. (2010).

New data (leg. Sîrbu I. and Sîrbu M., 2011): Semenicului Valley (S1), Grădişte brook (S2), brook at Brebu Nou (S3), Timiş riverbed downstream Trei Ape Lake (S6), along its course further to Teregova (S7), in the Timiş-Cerna corridor up to the Piatra Scrisă Monastery. In the rest of its flow, the species was no longer found due to the mechanical damage of the riverbed, caused by anthropic activities. 


\section{Classis Bivalvia Linnaeus, 1758 \\ Ordo Unionoida Stoliczka, 1871 \\ Familia Unionidae Rafinesque, 1820}

18. Unio pictorum (Linnaeus, 1758)

References: Sîrbu et al. (2010).

New data (leg. Sîrbu I. and Sîrbu M., 2011): empty shells at Hitiaş (S14), living individuals at Albina (S15), Şag (S16), shells at Rudna (S17), scattered individuals at Grăniceri (S18).

19. Unio tumidus Philipsson, 1788

References: Sîrbu et al. (2010).

New data (leg. Sîrbu I. and Sîrbu M., 2011): Timiş riverbed at Şag (S16).

20. Unio crassus Lamarck, 1819

References: Grossu (1962), Sîrbu et al. (2010).

New data (leg. Sîrbu I. and Sîrbu M., 2011): few individuals downstream Caransebeș (S10), at Lugojel (S11), increased number at Hitiaş (S14), highly abundant at Albina (S15) and Şag (S16), only empty shells at Rudna (S17) and several scattered individuals at Grăniceri (S18). Discontinuous distribution along the lower sector of the river.

21. Anodonta cygnaea (Linnaeus, 1758)

References: Sîrbu et al. (2010).

New data (leg. Sîrbu I. and Sîrbu M., 2011): Timiş River at Hitiaş (S14), Albina (S15), Şag (S16) and Grăniceri (S18);

22. Anodonta anatina (Linnaeus, 1758)

References: Sîrbu et al. (2010).

New data (leg. Sîrbu I. and Sîrbu M., 2011): Timiş River at Albina (S15) and Grăniceri (S18)

23. Sinanodonta woodiana (Lea, 1834)

References: Sîrbu et al. (2010).

New data (leg. Sîrbu I. and Sîrbu M, 2011): Timiş River at Hitiaş (S14), Albina (S15), Şag (S16) and Grăniceri (S18);

24. Pseudanodonta complanata (Rossmässler, 1835)

References: Sîrbu et al. (2010).

New data (leg. Sîrbu I. and Sîrbu M., 2011): only empty shells at Hitiaş (S14), living individuals at Albina (S15) and Şag (S16).

Ordo Veneroida H. and A. Adams, 1856

Familia Corbiculidae J. E. Gray, 1874

25. Corbicula fluminea (O. F. Müller, 1774)

New data (leg. Sîrbu I. and Sîrbu M., 2011): alien invasive species; until the 8th of August 2011 it was known in Romania inhabiting only the Danube River. This is the first finding in other inland waters of the country. Timiş River at Rudna (S17) and Grăniceri (S18).

Familia Sphaeriidae Deshayes, 1855 (1820)

26. Musculium lacustre (O. F. Müller, 1774)

New data (leg. Sîrbu I. and Sîrbu M.): Trei Ape Lake (S5);

27. Pisidium amnicum (O. F. Müller, 1774)

References: Sîrbu et al. (2010).

28. Pisidium casertanum (Poli, 1791)

References: Sîrbu et al. (2010).

New data (leg. Sîrbu I. and Sîrbu M., 2011): brooks and puddles in the Semenic Valley (S1), brooks and springs near Brebu Nou (S3), brooks close to Trei Ape Lake (S4), Timiş River downstream the Trei Ape Lake (S6), brooks close to Teregova (S7). 
29. Pisidium personatum Malm, 1855

References: Sîrbu et al. (2010).

30. Pisidium milium Held, 1836

References: Sîrbu et al. (2010).

31. Pisidium subtruncatum Malm, 1855

References: Sîrbu et al. (2010).

New data (leg. Sîrbu I. and Sîrbu M., 2011): Trei Ape Lake (S5), Timiş River downstream Caransebeş (S10).

Up to the present there are 31 species of aquatic molluscs known from the Romanian sector of the Timiş River. Among them are 17 species of gastropods and 14 of bivalves. The main feature of the mollusc communities in this river is the presence in the lower sector of all the seven naiads species that live in our freshwaters, something that is extremely rarely found in Romania. Before 1998, when the authors begun their research, only five species of freshwater molluscs have been quoted in the Timiş River basin. Between 1998 and 2002, 24 species have been found and their location as well as distribution on longitudinal gradient was documented (Sîrbu et al., 2010). In the last field investigation in August 2011, 22 species were found. Among them five are new findings in this basin. Considering the past and new data about the Mollusca and the observations on the ecological state of the river and its surroundings, several sectors can be distinguished along its longitudinal gradient, characterized by specific composition and communities' structure, environmental features, human impact sources and related issues. The changes occurred across time and space, as well as the characterization of the mentioned sectors are discussed below.

\section{Temporal and spatial changes of freshwater molluscs' populations and communities along the Timiş River, due to environmental features and human impact issues. Ecological classification of the Timis River sectors.}

In order to establish a realistic classification of the Timiş River sectors based on reliable basis, a multicriterial system has to be considered. This is based on temporal and spatial (longitudinal gradient analysis) changes in specific composition of freshwater molluscs communities, specific diversity, the type and state of specific habitats, bioindication value of some species, water flow features, Unionidae communities structure and changes in relation to anthropic activities, as well as the placement, types and pressure of impact sources. Based on these criteria and all the available information that could be gathered in the field researches, as well as from references, the main ecological classification of the river sectors' and their specific features and issues are given below.

\section{Sector 1. The mountains sector, between the springs and the Trei Ape Lake}

It is inhabited by a characteristic flowing, well oxygenated waters, hard substratum, confined Mollusca fauna, with rheophyllic (Ancylus fluviatilis) or krenbiotic species (Bythinella dacica), and some species adapted to small stagnant or flowing waters, which can be frozen or dried out most part of the year. The human impact in this sector is generally reduced, being caused by collateral effects of forest exploitation, road developments, tourism facilities, and traditional economical activities. 


\section{Sector 2. The Trei Ape Lake}

This is an artificial lake, formed by the building of a dam in the spring area, for economic purposes. The main three rivulets that flow together and form the Timiş River supply it. Being a new, atypical habitat for the surrounding mountain landscape, it was surely colonized from outside, by some lentic, psamo-pelophylic and macrophytophylic freshwater mollusc species. It causes also physical and chemical changes in the water features downstream, as well as a fragmentation of the longitudinal distribution of some native species. Some species have been found only in this sector, like Radix balthica, Ferrissia wautieri, and Musculium lacustre. During the past decades, but especially in the last few years, the tourism has flourished in the area, the high number of facilities and humans, especially during holydays, represent obvious sources of impact, especially linked to habitat degradation, hips of wastes found everywhere, bathing and overfishing, household wastewater discharges in the lake and tributaries from an accelerated growing number of buildings and villas, etc.

Sector 3. The Timiş River between the Trei Ape Lake and Teregova (entrance in the Timiş-Cerna corridor)

This sector is the remaining part of its mountain course, behaving like a typical river for this elevation and landscape, and sheltering the characteristic Mollusca fauna. Downstream the lake its impact is obvious. However, the steep slope and velocity of the water help the selfcleaning processes, and after a short sector it has all the features of a mountain river, sheltering once again the specific Mollusca fauna.

\section{Sector 4. The Timiş River sector in the Timiş-Cerna corridor, downstream to the town of Caransebeș.}

Comparing the state of the river witnessed in 2011 to that observed during the 1998 2002 field campaigns, a debasemant of its ecological state is obvious along this sector. The main cause is the destruction of the riverbed caused by the so-called recalibration of the valley, and the many ballast excavations along the river's course. The bulldozers, excavators, and shovels operate within the riverbed, and the whole riverscape is destroyed. The trucks are loaded on both sides of the river and displace huge amounts of sediments and ballast. The working points are frequently found along the main part of the lower stretch of this sector. In some areas, there are no living molluscs at all, and most benthic groups are absent, because the whole substratum is or was rummaged and there is no more natural habitat. The rheooxyphyllic species Ancylus fluviatilis inhabits a much shorter sector than it used during the beginning of this century, and its distribution is discontinuous along the sector where it still lives. Its last sampling point in 2011 along the river was in the Timiş-Cerna corridor at Piatra Scrisă (S8) Monastery. The anthropic destruction of the entire rivers' ecosystems are outraging.

\section{Sector 5. The Timiş River between the town of Caransebeş and Coșteiu Village}

This sector is delimited by the main locality of the entire region, Caransebeş town, and the location where the river's water is drained towards the river Bega, by the artificial TimişBega canal. The ecological state of this sector was significantly degraded in 2011 compared to the status recorded in 1998-2002, the causes being the same as those mentioned for the previous sector. The riverbed and its specific habitats are severely denaturized by ballast excavations and hydrotechnical works, the sedimentation is excessive, communities are poor and the longitudinal range of most mollusc species are highly fragmented. There are some patches inhabited by Unio crassus, but their number, as well as the abundance of the species, are lower than it was noticed one decade before. 


\section{Sector 6. Downstream the dam from Coșteiu Village}

The dam was built here in order to capture the water and lead it through the TimişBega canal. The sector downstream this dam, is the most destroyed and degraded, compared to all the other sectors, because the physical damage of the riverbed. No natural features of the valley's river are present. Not a single mollusc species has been found in the river, a fact that proves the extreme damage of the ecosystem.

\section{Sector 7. The Timiş River sector between Hitiaş and Şag villages}

An improvement of the ecological status is recorded, proving the river's capacity of self-cleaning and recovering. Although ballast excavations and hydrotechnical works are still present and interrupt the continuity of specific habitats as well as the river's continuum, the mollusc communities are still capable to adequate to this fluctuant environment and to colonize the microhabitats available during the periods of relative stability. The Mollusca fauna and communties' structure indicate a more altered state than one decade before, but the improvement, considering the status of the upstream, as well as the downstream sector, is obvious. In present, it is still the best-preserved sector, in the middle and lower Timiş River.

At Hitias the authors sampled in 2011, by simple randomized sampling, 63 individuals of Unionidae, from a sandy layer, close to the riverbank, the specific habitat. The community structure in terms of relative abundance (RA\%), as well as relative dominance - ratio of weight $(\mathrm{RD} \%)$, considering the total mass of living individuals, are given in figure 1, respectively in figure 2. Unio crassus is prevailing in terms of abundance (81\%), while the alien invasive species Sinanodonta woodiana is the dominant species in terms of weight $(66 \%)$.

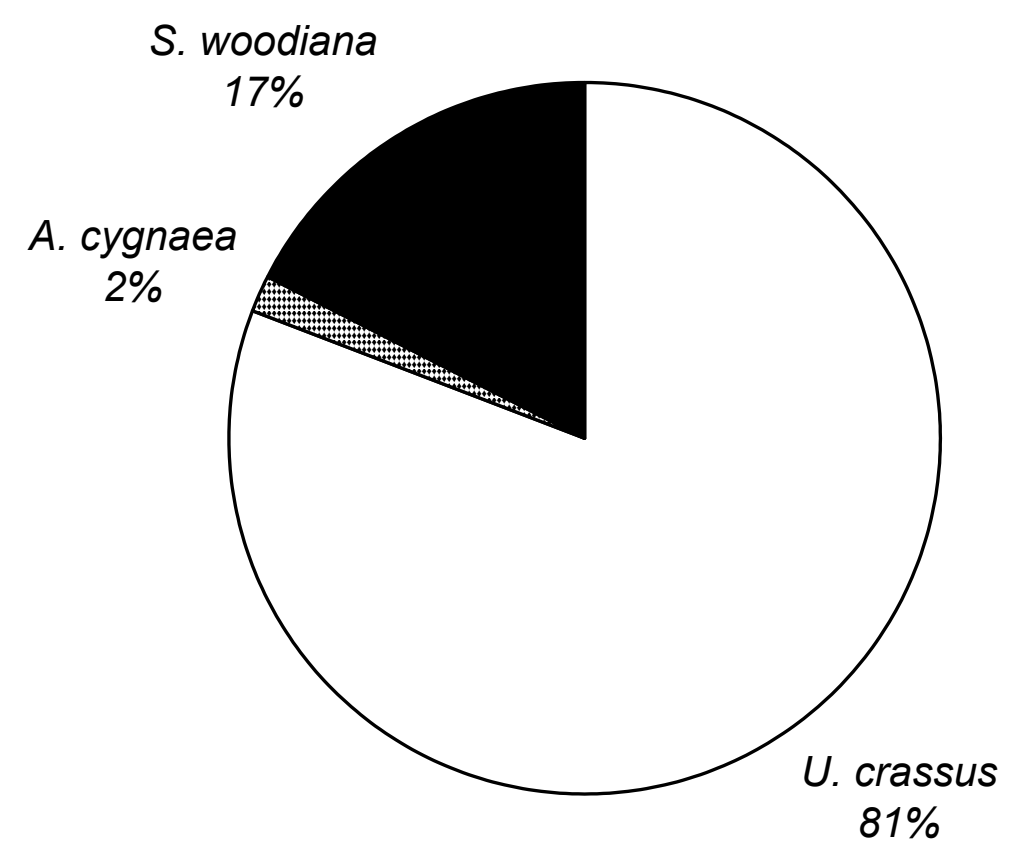

Figure 1: The Unionidae community structure in the Timiş River at Hitiaş (S14), in terms of relative abundance (RA\%); 63 individuals were randomized sampled in August 2011. 
In the year 2002, at the same level, there were values of $60 \%$ RA and $55 \%$ RD for Sinanodonta woodiana, while for Unio crassus the values were of $20 \%$ RA and $15 \%$ RD (Sîrbu et al., 2006). Comparing the two structures, it is possible that, in time, U. crassus became more abundant, while $S$. woodiana is represented by fewer individuals, but these are heavier, consolidating its dominance within the community. This fact might suggest a new phase in the colonizing strategy of the alien invasive species, maybe a switch from the former r-selected invasive level (in 2002 there were many young individuals), towards a K-selection trend of population dynamics.

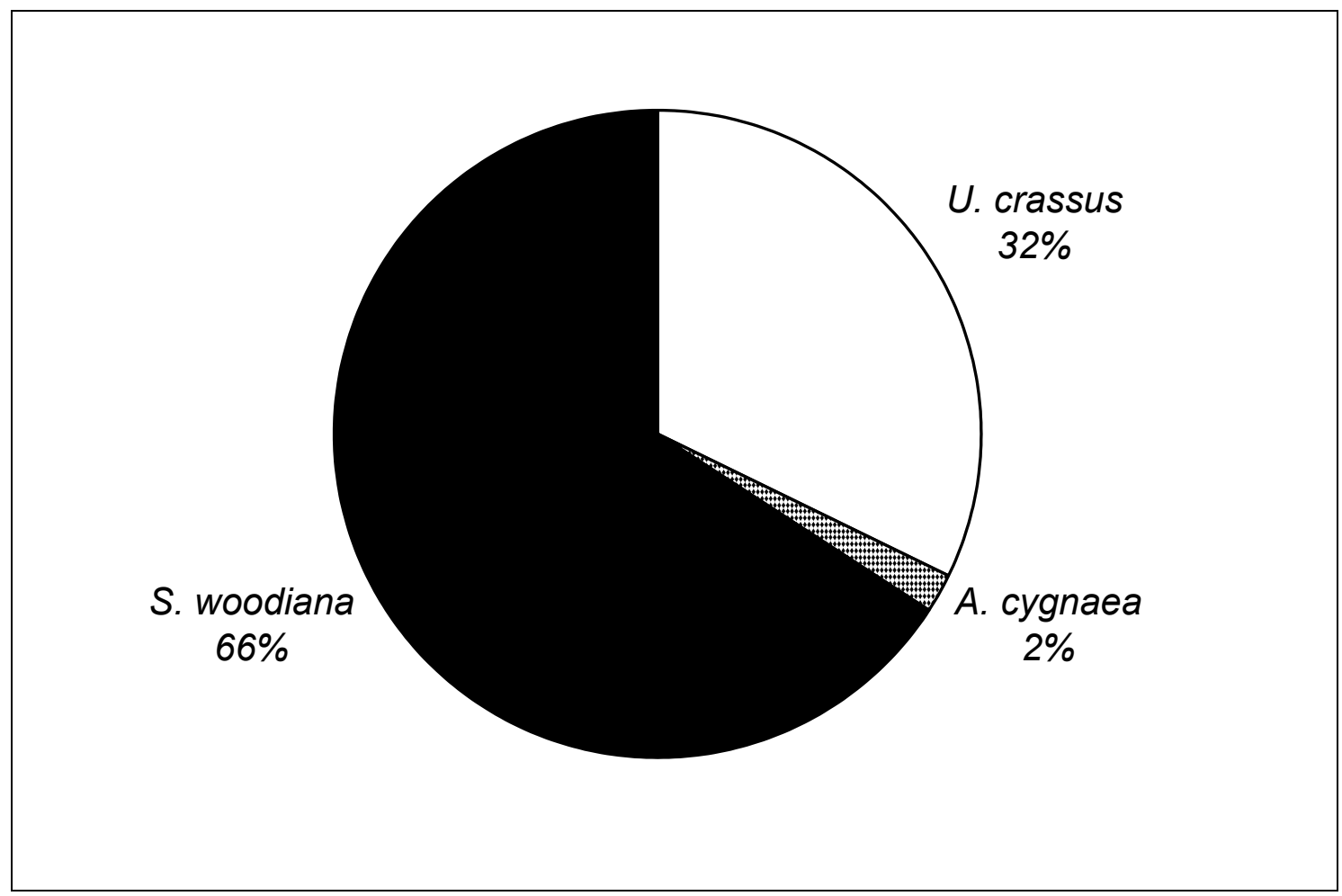

Figure 2: The Unionidae community structure in the Timiş River at Hitiaş (S14), in terms of relative dominance ( $\mathrm{RD} \%)$; the total weight of the 63 sampled individuals was $3876.5 \mathrm{~g}$.

In August 2011, the Unionidae community structure was also studied downstream, close to the village of Albina (S15), by the same means. 95 individuals were randomly sampled. They belong to five species. The relative abundance structure is given in Figure 3 and the relative dominance in Figure 4. Once again, Unio crassus is prevailing in terms of individuals' number, while in terms of dominance $U$. crassus and $S$. woodiana are co-dominant (39\% and, respectively 37\%). The difference between the structures of the last two sampling stations is most probably linked to the river's habitat features, but also to the human impact. At Hitiaş, the river was broad and disturbed by a ballast excavation, while at Albina there are no traceable human activities, at least not in the last few years, and the river is in a more natural condition. 


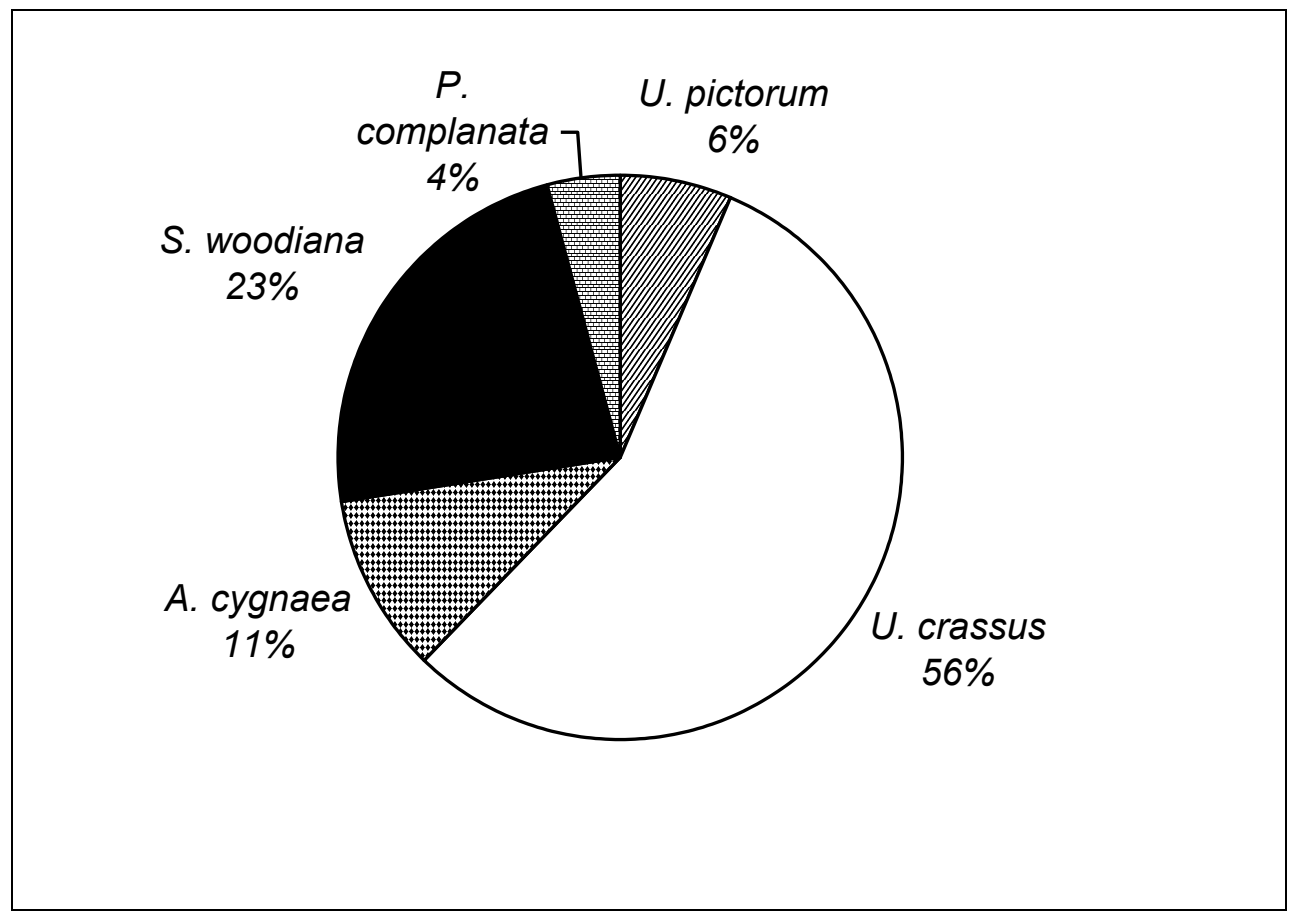

Figure 3: The Unionidae community structure in the Timiş River at Albina (S15) in terms of relative abundance (RA\%) - 95 individuals have been randomly sampled in August 2011.

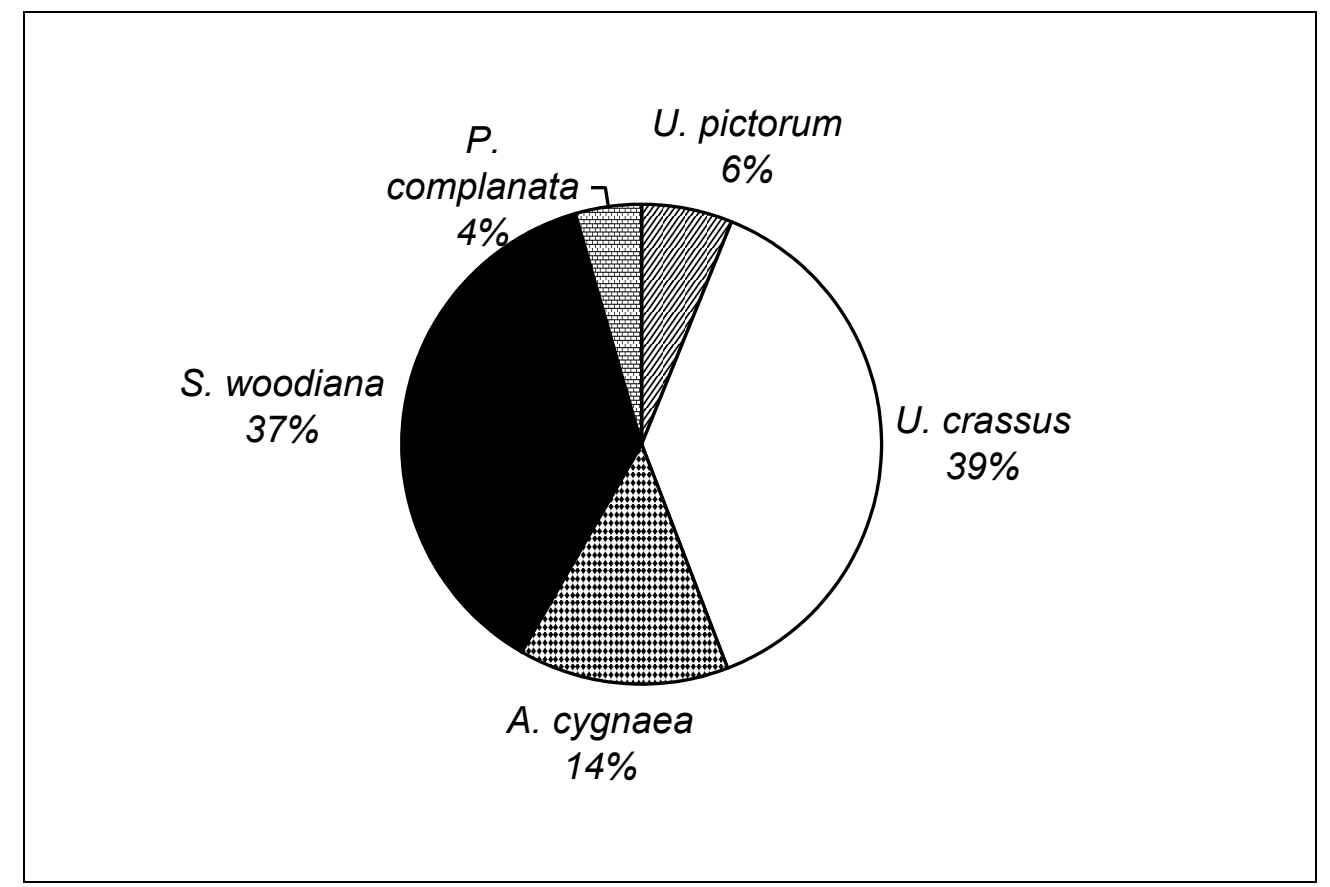

Figure 4: The relative dominance (RD\%) structure of the Unionidae community at Albina (S15); the total weight of the 95 individuals was $3622.7 \mathrm{~g}$. 


\section{Sector 8. The last sector on Romanian territory, between Şag and Grăniceri.}

In this sector occurs a new degradation of the river's ecological state, compared to the upstream adjacent sector. Both the riverbanks and the riverbed are artificially changed, ballast excavations are, or were in the past, placed too close, the hydrotechnical works, channeling and embankments destroy a large part of the river's structure and functions. In most parts, this sector looks almost like a human-made canal. A mass mortality of bivalves was observed, especially in the lower stretch, where specific habitats are scarce, and stable sediments are in small and rare patches distributed along and close to the riverbanks. Still, there are some areas with a relatively high diversity and abundance of molluscs, inclusively Unionidae and prosobranch gastropods. This is the sector in which, during the field survey accomplished in 2011, the authors have first found the alien invasive species Corbicula fluminea.

The Unionidae communities' dynamics shows the changes which took place in the last decade in respect of human pressure. In the upper reach of this sector, at Sag (S16), the river was investigated three times, in 2000, 2002 and 2011, by a longitudinal transect of about 1000 $\mathrm{m}$, centered in the bridge of the Timişoara - Deta road. Severe changes were obvious since the beginning of the study. In the year 2000 the river was literally paved with Unionidae, in crosssection, from one riverbank to the other, and all the seven species known form Romania were present (facts extremely seldom encountered in our waters), and their abundance was very high, the maximum exceeding 100 individuals $/ \mathrm{m}^{2}$. Among gastropods Lithoglyphus naticoides characteristically inhabited continuously the riverbed, in stripes close to the riverbanks. This sector hosted probably the most diverse and abundant community of naiads in the Romanian Western Plain. In the summer of 2002 the river was crossed by a small dam, built in the meantime, with a narrow opening in the middle part, which changed the whole riverbed structure and water flow features. The Unionidae community spatial dynamics was different than registered before. In order to show the spatial small-scale effect of this dam, we established three sampling stations: the first (1) at about $500 \mathrm{~m}$ upstream, the second (2) in the close vicinity of it at about 10-20 m, and the third (3) within of a $400 \mathrm{~m}$ line-transect downstream. The data are shown in table 2 and figure 5 (some data were partially published by Sîrbu et al., 2006).

Table 2: The Unionidae community structure at Şag, during the field-survey from 2002.

\begin{tabular}{|l|c|c|c|c|c|c|}
\hline \multicolumn{1}{|c|}{ Parameter and station } & $\begin{array}{c}U . \\
\text { tumidus }\end{array}$ & $\begin{array}{c}\text { U. } \\
\text { pictorum }\end{array}$ & U. crassus & A. anatina & $\begin{array}{c}\text { S. } \\
\text { woodiana }\end{array}$ & TOTAL \\
\hline 1. Above the dam & & & & & & \\
\hline No. of individuals & 4 & 3 & 11 & 0 & 0 & 18 \\
\hline RA\% & 22.22 & 16.67 & 61.11 & 0 & 0 & 100 \\
\hline Total weight (G) & 108 & 26.5 & 88 & 0 & 0 & 222.5 \\
\hline RD\% & 48.54 & 11.91 & 39.55 & 0 & 0 & 100 \\
\hline 2. At the dam & & & & & & \\
\hline No. of individuals & 2 & 0 & 3 & 4 & 4 & 13 \\
\hline RA\% & 15.38 & 0 & 23.08 & 30.77 & 30.77 & 100 \\
\hline Total weight (G) & 16 & 0 & 24.5 & 35 & 39.5 & 115 \\
\hline RD\% & 13.91 & 0 & 21.30 & 30.43 & 34.36 & 100 \\
\hline 3. Downstream & & & & & & \\
\hline No. of individuals & 0 & 1 & 49 & 0 & 0 & 50 \\
\hline RA\% & 0 & 2 & 98 & 0 & 0 & 100 \\
\hline Total weight (G) & 0 & 47.5 & 1710.5 & 0 & 0 & 1758 \\
\hline RD\% & 0 & 2.70 & 97.30 & 0 & 0 & 100 \\
\hline
\end{tabular}




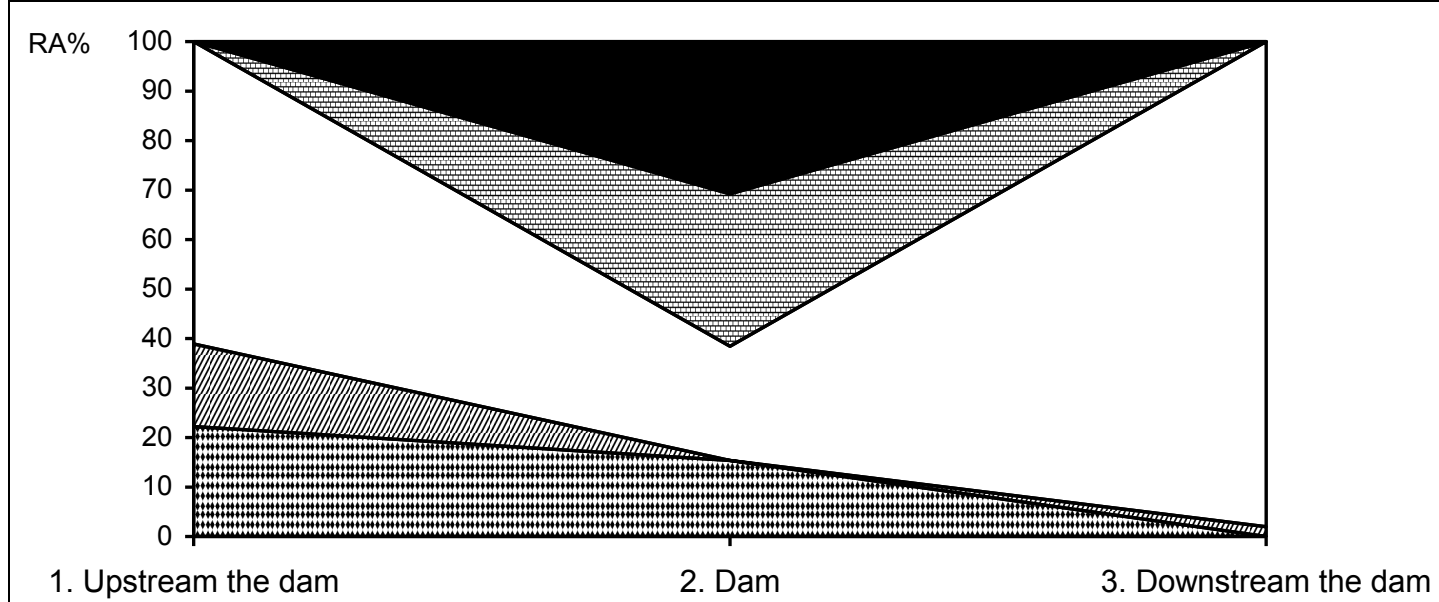

回U. tumidus 四U. pictorum $\square$ U. crassus 圈A. anatina $\mathbf{S}$. woodiana

Figure 5: The Unionidae community structure (in terms of relative abundance RA\%) and space-dynamics at small-scale in the Timiş River at Şag in the summer of 2002, showing the effect of a newly built dam across the river.

The dam built between the fall of 2000 and the summer of 2002, caused a steep reduction of naiads' abundance as well as diversity (two out of five species have not been found). The slowing of the water flow upstream the dam (station 1), still is prone for all the three Unio species; close to the dam the slow speed and muddy sediments, favor the settlement of a lentiphyllous community: the rheophyllic species $U$. crassus shows a low RA\% value, being outnumbered by $A$. anatina as well as $S$. woodiana. Downstream the dam, the river flows with high velocity, the favourable sediments are placed in a narrow band along one riverbank, the single microhabitat inhabited by naiads, and the community consists almost only of $U$. crassus (best adapted to these conditions), while only one individual of U. pictorum was found within the sampling transect.

This case study has two meanings: showing how a simple human activity in the riverbed causes serious changes in the communities, and how finely tuned the Unionidae may respond, and adequate to this newly formed conditions.

In 2011, the status of the naiads above the dam (also about $500 \mathrm{~m}$ upstream), was different. 108 individuals were sampled by simple randomized method, from the specific habitat ( $0.5-2 \mathrm{~m}$ from the riverbank). U. crassus prevailed both in terms of abundance and weight (Fig. 6 and Fig. 7), while all the other species show values below $10 \%$. Considering the ratios, they seem like those registered in 2002, but the total abundance of the community increased significantly. The naiads were found in densities with maximum values exceeding 100 individuals $/ \mathrm{m}^{2}$, as it was stated in the year of 2000, before the dam was built. During the last decade, the community has recovered and structured adequately. This is a new proof of the river's capacity of resilience, but also a measure of the Unionidae populations and communities' ecological adaptability. 


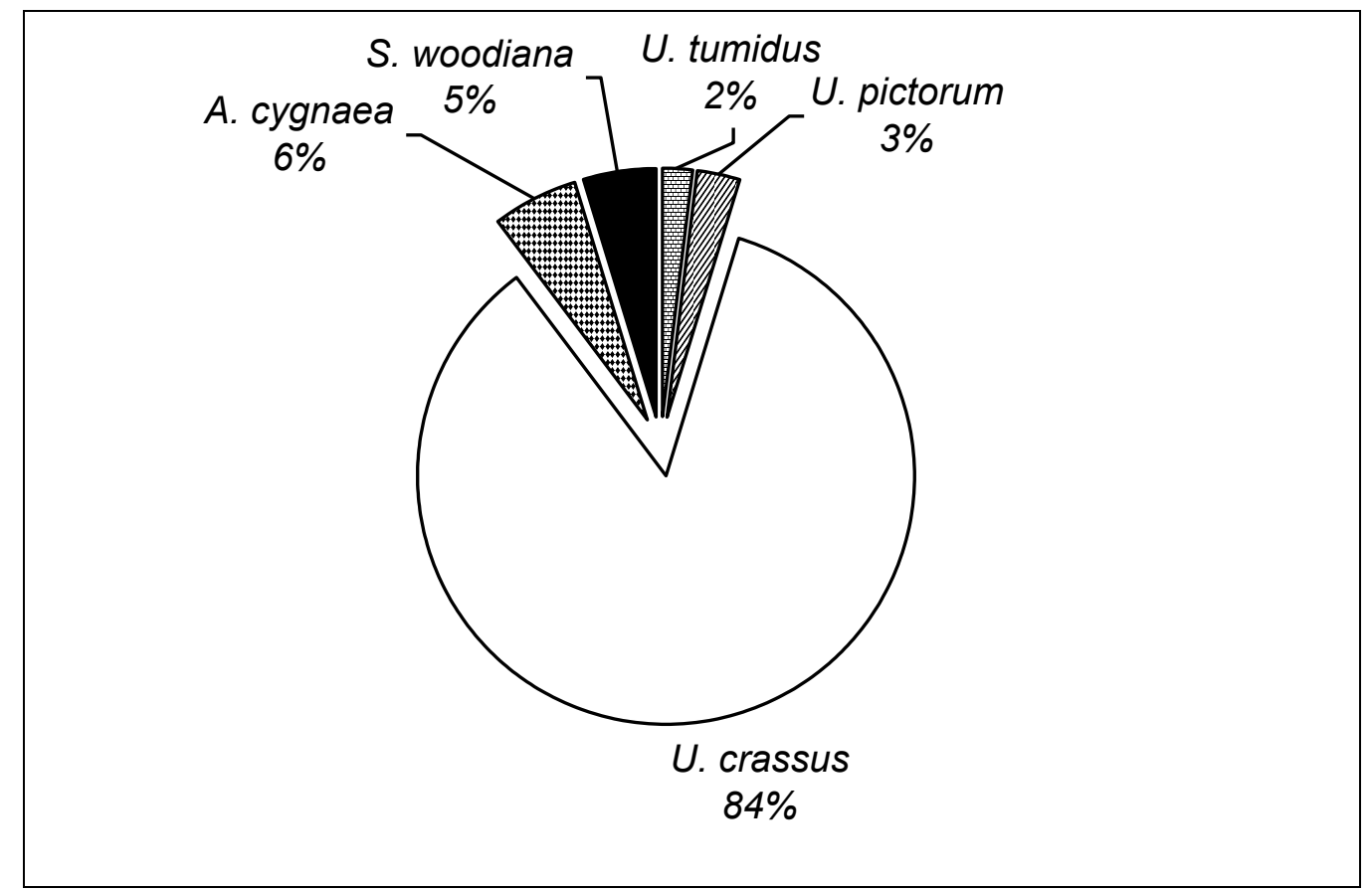

Figure 6: The Unionidae community structure in terms of relative abundance (RA\%) in the Timiş River at Şag (S16) in August 2011 - 108 individuals were randomly sampled.

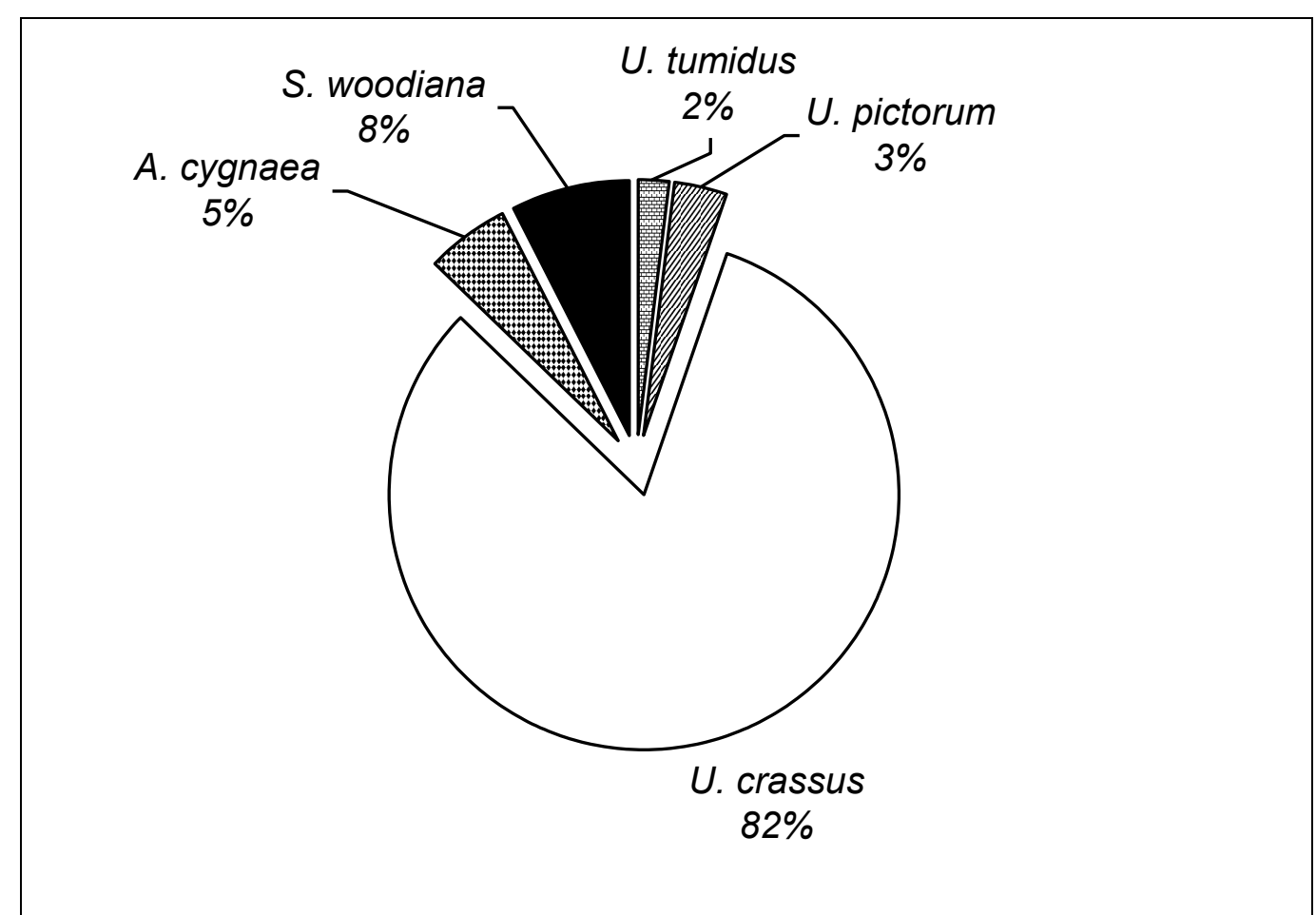

Figure 7: The Unionidae community structure in terms of relative dominance (RD\%) in the Timiş River at Şag (S16) in August 2011 - the total weight of the 108 sampled individuals was $2798.5 \mathrm{~g}$. 
During the field survey from 2011, downstream Şag Village, at Rudna (S17) and Grăniceri (S18), the last locality on Romanian territory, as well as the final location of this study, the river is once again degraded by ballast excavations, embankments, and hydrotechnical works. At Rudna (S17) a mass-mortality of naiads and a very low diversity of molluscs were noticed. In the last sampling station, at Grăniceri (S18), the river embankment is ongoing, and the water flow is linear between high narrow banks. There is no flood area anymore. Only along one riverbank, less destroyed, a narrow band of sand still shelters scattered individuals of naiads, placed in a single, interrupted row. Along a $200 \mathrm{~m}$ transect, a reduced number of Unionidae (34 individuals) were found, sampled, analyzed, and released. The relative abundance structure of this poor community is shown in figure 8. Once again, $U$. crassus prevails in terms of abundance ( $85 \% \mathrm{RA})$, while the other three species show reduced ratios. Most likely these are not confined to this habitat, but drifted from upstream sectors.

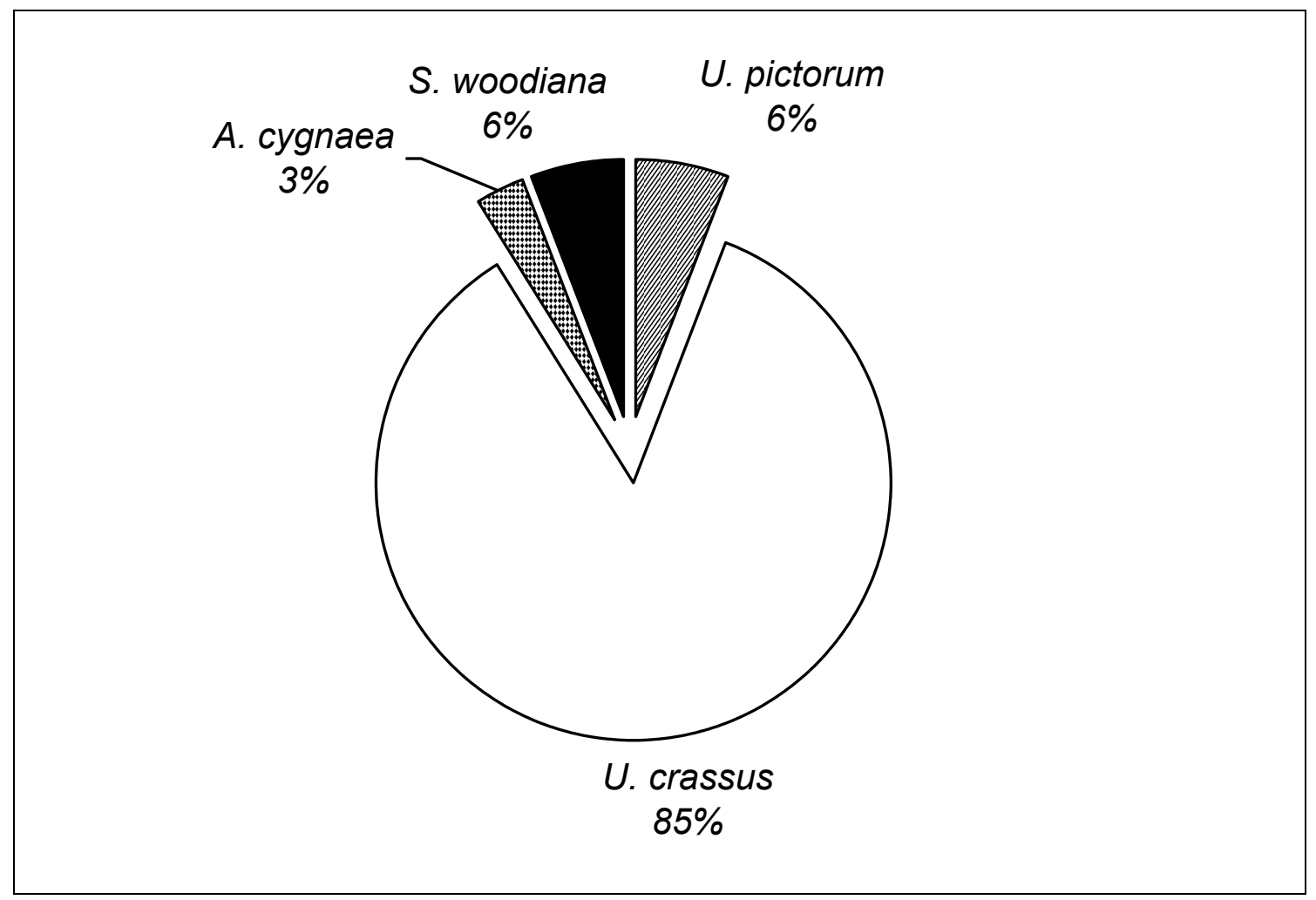

Figure 8: The Unionidae community structure in terms of relative abundance (RA\%) in the Timiş River at Grăniceri (S18) during August 2011 - 34 individuals were sampled along a $200 \mathrm{~m}$ line transect. 


\section{CONCLUSIONS}

In the Romanian area of the Timiş River basin, most of its ecological systems are of high quality in their upper sectors (Fig. 9), but prove certain effects of the human impact in their middle and lower sectors.

This river was drastically and unjustifiably degraded, from ecological point of view, during the last decades, and especially in the last years, mainly by mechanical human impact (hydrotechnical plants, embankments, ballast excavations, dams, etc.).

Some sectors are highly damaged (Fig. 10 and Fig. 11), and present a debasement of environmental quality and alteration of the lotic ecosystems' structure and functions.

By contrast to other rivers of Romania, the chemical and biological pollution seem relatively reduced and have a lesser impact.

Despite these facts, the Timiş River still has a remarkable self-cleaning and selfsustaining potential, proved by some sectors with improved ecological state, respectively by the higher parameter values of some freshwater mollusc communities, with certain environmental demands. They have narrow ecological valences, sustaining a series of essential functions of this riverscape (like those of water filtering and cleaning, stabilizing substratum and facilitating the sedimentation, reducing turbidity, being essential resources for other foodlevels and links within the tropho-energetic structure, etc.).

Against all odds, this river still shelters high abundances of bivalves and gastropods of ecological and sozological value, but the increasing and ongoing human impact could be a certain menace in the future.

There is still a remarkable and abundant population of Unio crassus (Fig. 12), a species included in Annex II of EUHSD (92/43/EEC 1992), also known as the Habitats Directive, which inhabits especially the Hitiaş-Şag river sector, but in full decrease of its ecological quantitative parameters between the localities Caransebeş and Coşteiu, as well as in the last lower sector, until the Romanian - Serbian border.

The lower Timiş River sectors shelters also an abundant population of Pseudanodonta complanata (Fig. 13), a species that is strictly protected by the Romanian legislation.

According to the evidence of the field surveys, as well as to the aquatic mollusc communities spatial dynamics, the Romanian sector of the Timiş River can be divided in eight different sectors, delimited by ecological and human impact features. 


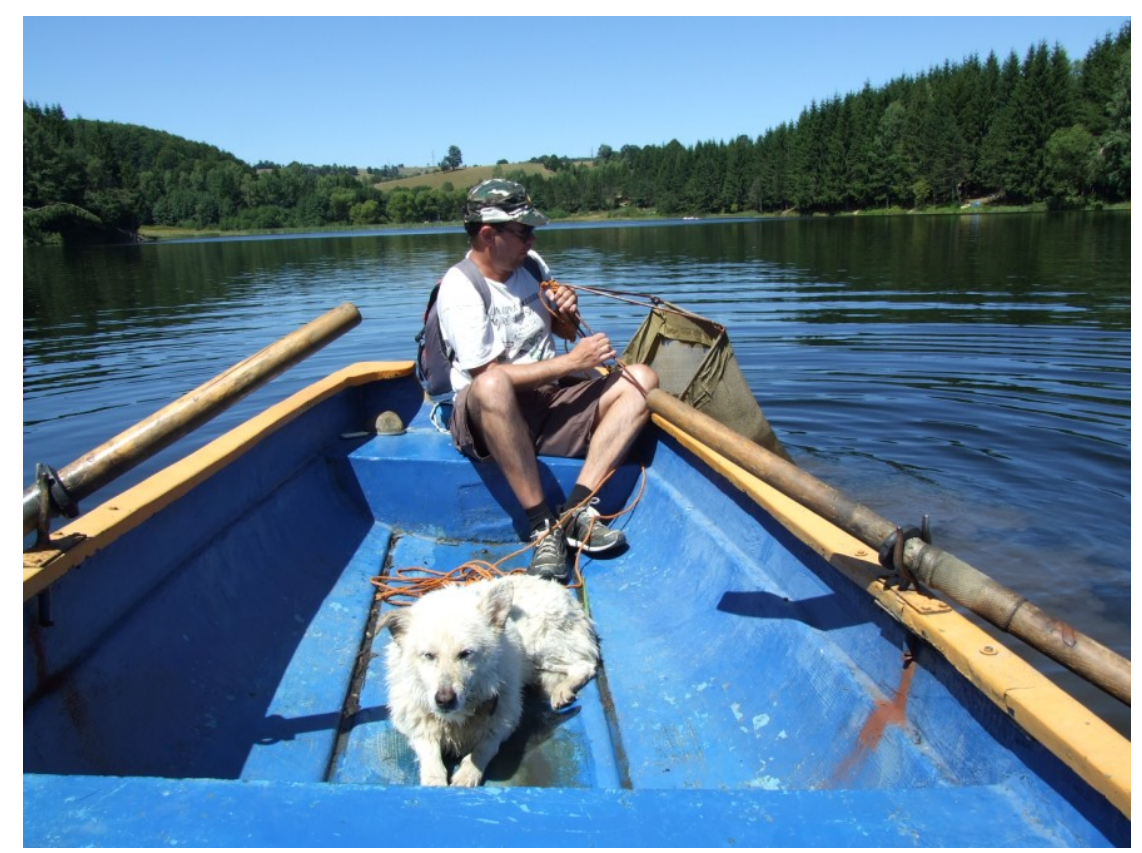

Figure 9: Dredging in the Trei Ape Lake, in the source area of the Timiş River (August, 2011).

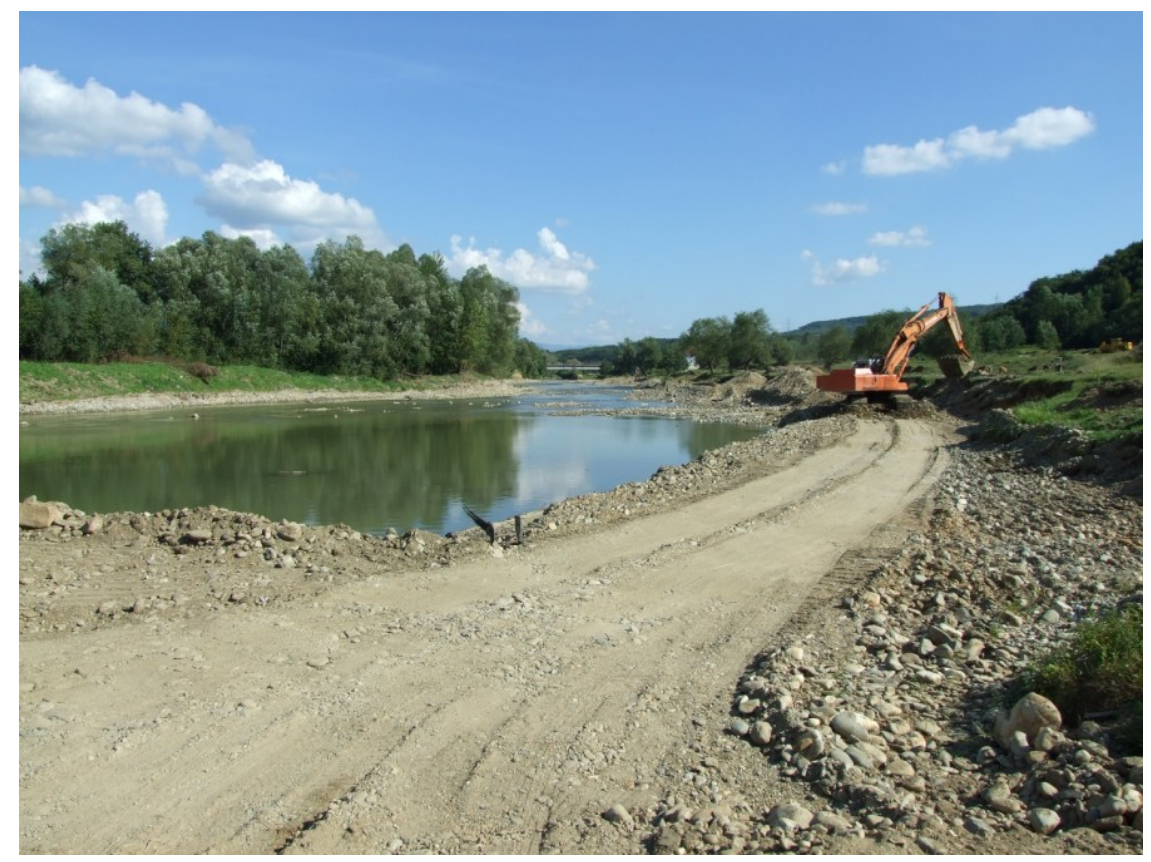

Figure 10: Physical damage of the riverbed along most parts of the middle and lower Timiş sectors is the main threat for the riverscapes' structure and function.

All the hydrotechnical works and ballast excavations should be planned on ecological and environmental friendly basis. 


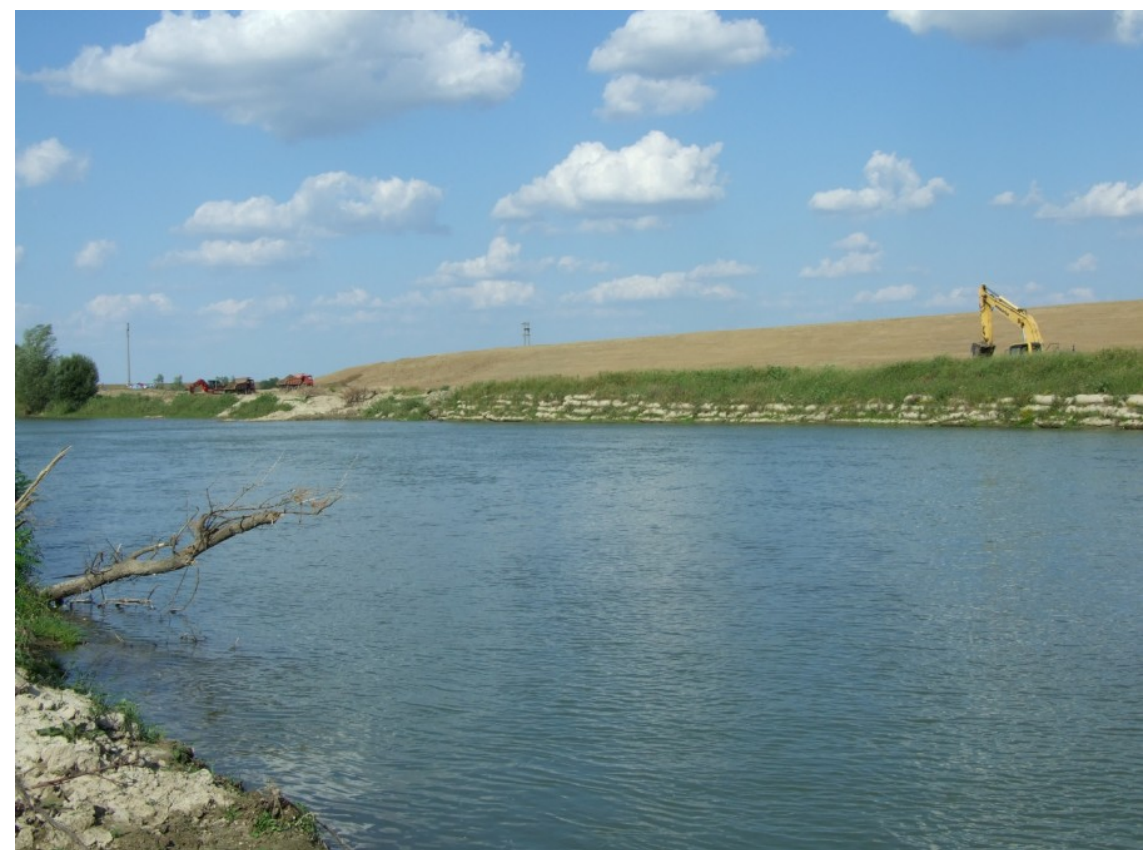

Figure 11: The Timiş River at the last sampling station at Grăniceri (S18), close to the border with Serbia; the anthropic impact is obvious and ongoing (August, 2011). In the sandy bottom the alien invasive species Corbicula fluminea lives in high abundances.

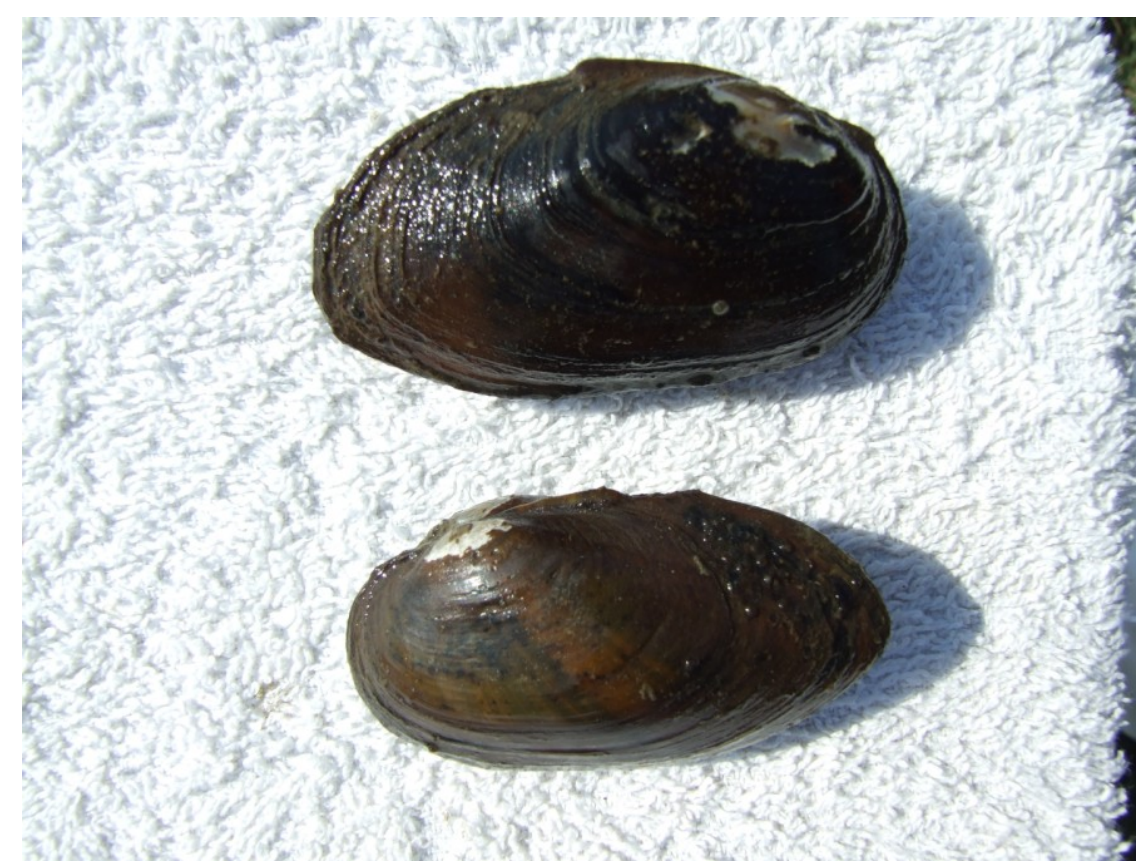

Figure 12: Unio crassus sampled from the Timiş River at Albina Village (S15) in August 2011. It is a flag-species included in Annex II of the EUHSD (92/43/EEC 1992), also known as the Habitats Directive. 


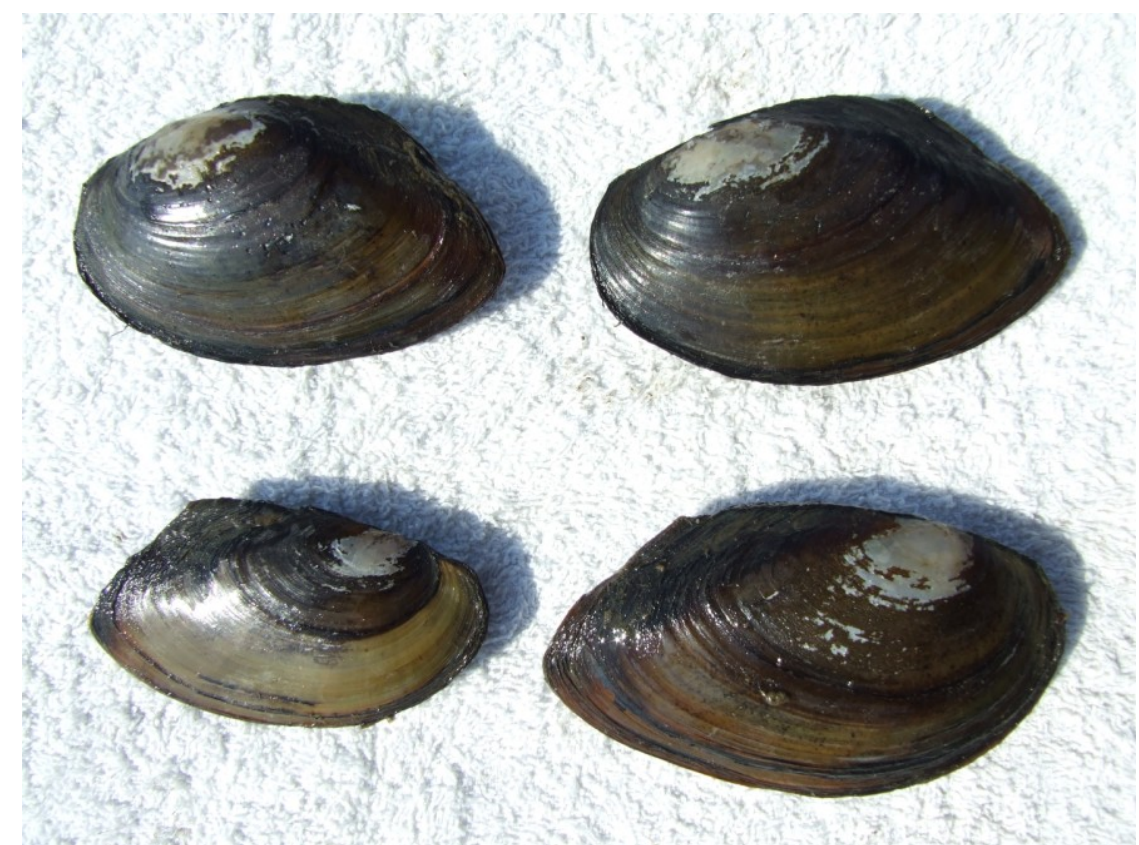

Figure 13: Pseudanodonta complanata sampled from the Timiş River at Albina Village (S15) in August 2011. It is a strictly protected species by the Romanian legislation.

\section{ACKNOWLEDGEMENTS}

During the past two decades a valuable help and scientific assistance was provided by $\mathrm{Mr}$. Glöer P., which donated us a large part of the literature and revised biological material used also in this paper. Scientific assistance was also provided by the late Mr. Bănărescu P. M. and Sárkány-Kiss A. The field survey from August 2011 was done in the frame of "Study of the quality of Timiss water and registry of polluters source to border" (IV.1.2), a Phare CBS contract, no. 411 - 90964/30.12.2010/07 of "Lucian Blaga" University, Faculty of Sciences, financed by the European Community. Special regards and gratitude to Ms. Benedek A. M., for all the help provided for the establishing of this paper. To all those mentioned, as well as to the anonymous referees of this paper, the authors owe sincere gratitude. 


\section{REFERENCES}

1. Araujo R., 2009 - Fauna Europaea v. 2.6 .2 (last update August 2013); Mollusca, Bivalvia. Fauna Europaea version 2.0 (updated December, 2009), http://www.faunaeur.org (accessed, September 2013).

2. $\quad$ Bank R. A., 2011 - Fauna Europaea v. 2.6.2 (last update August 2013); Mollusca, Gastropoda. Fauna Europaea version 2.4 (updated January, 2011), http://www.faunaeur.org (accessed, September 2013).

3. Bănărescu P. M. and Sîrbu I., 2002 - Contribution to the knowledge of the Banat aquatic fauna. Studies in Biodiversity - West Romania Protected Areas, Timişoara, 108-115.

4. Bielz A. E., 1867 - Fauna der Land- und Süsswasser-Mollusken Siebenbürgens. Zweite Auflage, Comissions-Verlag v. Filtsch, Hermannstadt, 216. (in German)

5. Clessin S., 1887 - Die Molluskenfauna Oesterreich - Ungarns und der Schweiz, II Theil, Nürnberg, Verlag von Bauer und Raspe, 318. (in German)

6. Glöer P., 2002 - Die Süsswassergastropoden Nord- und Mitteleuropas, Bestimmungsschlüssel, Lebensweise, Verbreitung. Die Tierwelt Deutschlands, 73. Teil., ConchBooks, 327. (in German)

7. Glöer P. and Meier-Brook C., 2003 - Süsswassermollusken, DJN - Hamburg, 134. (in German)

8. Grossu A. V., 1962 - Bivalvia. Fauna R.S.R., Edit. Acad., Bucureşti, 3, 3, 427. (in Romanian)

9. Grossu A. V., 1986 - Gastropoda Romaniae, 1; I. Caracterele generale, istoricul şi biologia gastropodelor; II. Subclasa Prosobranchia şi Opistobranchia. Edit. Litera, Bucureşti, 524. (in Romanian)

10. Grossu A. V., 1987 - Gastropoda Romaniae, 2; Subclasa Pulmonata, I. Ordo Basommatophora, II. Ordo Stylommatophora (Suprafamiliile Succinacea, Cochlicopacea, Pupillacea), Edit. Litera, Bucureşti, 5-166. (in Romanian)

11. Kimakowicz M. v., 1883-1884 - Beitrag zur Molluskenfauna Siebenbürgens. Verhandlungen und Mitteilungen der Siebenbürgischen Vereins für Naturwissenschaften in Hermannstadt, 3334, 13-83, 57-116.

12. Sîrbu I., 2002 - The genus Pisidium C. Pfeiffer, 1821 (Bivalvia, Veneroida, Pisidiinae) in Banat (Romania), Acta oecologica, Universitatea “Lucian Blaga” Sibiu, 9, 1-2, 55-66.

13. Sîrbu I., 2004 - Freshwater molluscs communities from the Timiş River Basin (Romania), Acta oecologica, Universitatea “Lucian Blaga” Sibiu, 11, 1-2, 185-194.

14. Sîrbu I. and Benedek A. M., 2004 - The genus Pisidium C. Pfeiffer 1821 (Bivalvia: Sphaeriidae: Pisidiinae) in the Romanian Inner Carpathian Basin, Travaux du Muséum National d'Histoire Naturelle "Grigore Antipa”, Bucharest, 47, 7-21.

15. Sîrbu I., Sárkány-Kiss A., Sîrbu M. and Benedek A. M., 2006 - The Unionidae from Transylvania and neighboring regions (Romania), Heldia, München, 6, 3-4, 151-160.

16. Sîrbu I., Sîrbu M. and Benedek A. M., 2010 - The freshwater mollusca from Banat (Romania). Travaux du Muséum National d'Histoire Naturelle "Grigore Antipa”, Bucharest, 53, 21-43.

17. Sîrbu I., 2011 - Studiu faunistic, chorologic şi ecologic al moluştelor acvatice din râul Timiş (sectorul din România), cu observaţii asupra valorii bioindicatoare şi a efectelor impactului antropic, in Studiu privind calitatea apei râului Timiş, de la izvoare la granița cu Serbia. Măsuri de protecţie a râului Timiş - Step II. Contract 411/Primăria Caransebes/90964/30.12.2010/07. Program de cooperare transfrontalieră România - Serbia, 101 - 129 (www.romania-serbia.net). (in Romanian)

18. Welter-Schultes F., 2012 - European non-marine molluscs, a guide for species identification, Planet Poster Editions, Göttingen, 679. 